\title{
Recovery of the Endangered giant otter Pteronura brasiliensis on the Yavarí-Mirín and Yavarí Rivers: a success story for CITES
}

\author{
MARIBEL RECHARTE USCAMAITA and RichaRD BodMeR
}

\begin{abstract}
The giant otter Pteronura brasiliensis was hunted almost to extinction in the Peruvian Amazon during a period of professional trade in wild animal skins during 1920-1973. In 1973 the Department of Agriculture of Peru (INRENA) prohibited commercial hunting in the Peruvian Amazon, and the giant otter was included in Appendix I of CITES. From 1973 to 2004 giant otter populations experienced a slow recovery in numerous rivers of the Peruvian Amazon. Here, we report the population growth of the giant otter on the Yavarí-Mirín and Yavarí Rivers in northeast Peru. The first evaluations of giant otter populations in these rivers, in which no individuals were sighted, were in 1992-1993. During surveys in 1996 and 1997 two individuals were sighted. In 2001, 19 individuals were sighted and in 2003 and 2004, 41 individuals were observed. This increase demonstrates a slow recovery and shows that the population has not yet reached its carrying capacity. The prohibition of international trade in otter skins by CITES, supported by INRENA, helped the population recover and was important in the conservation of this species.
\end{abstract}

Keywords Amazon, CITES, giant otter, Peru, population growth, Pteronura brasiliensis, Yavarí-Mirín

\section{Introduction}

The giant otter Pteronura brasiliensis is endemic to 1 South America, ranging from the Llanos of Colombia and Venezuela to the north-east of Argentina, including the Amazon basin (Carter \& Rosas, 1997). Professional hunting for the skins of giant otters began in c. 1920 and continued until 1973 (Smith, 1981; Carter \& Rosas, 1997). During the period of legal exploitation giant otter skins were considered one of the best furs in international markets (Utreras \& Jorgenson, 2003). A hunter would receive the equivalent of USD 50 for a single giant otter skin, which would be worth c. USD 250 when it reached Europe or the USA (Smith, 1981). High demand led to indiscriminate hunting

Maribel Recharte Uscamaita (Corresponding author) Facultad de Ciencias Biológicas, Universidad Nacional de la Amazonia Peruana, Pevas \#5, Iquitos, Peru. E-mail maribel_recharte@yahoo.com

RICHARD BODMER Durrell Institute of Conservation and Ecology, University of Kent, Canterbury, UK.

Received 19 April 2008. Revision requested 2 October 2008.

Accepted 13 December 2008. throughout the species' geographical range, resulting in global decline and local extinctions in many areas (Eisenberg, 1989; Carter \& Rosas, 1997).

The Peruvian Amazon exported 23,980 giant otter skins between 1946 and 1973 to Germany, England, Switzerland and the USA (Smith, 1981). Large numbers of skins were exported between 1946 and 1960 but after 1960 the number declined gradually until the early 1970 s when very few skins were exported (Pacheco, 1983; Fig. 1). As the demand, value and legality of giant otter skins did not change during this period the reduction in export was probably because of drastically reduced numbers of giant otters in areas accessible to professional hunters. Following this decline giant otter numbers remained low, and the species is categorized as Endangered on the IUCN Red List (Duplaix et al., 2008).

On the Yavarí and Yavarí-Mirín Rivers of north-east Peru hunting during the period of commercial use of giant otter skins reduced the population to remnant levels whilst the otter's habitat remained relatively untouched (Bodmer \& Puertas, 2003). The Yavarí and Yavarí-Mirín area now contains healthy populations of many other large mammal species (Salovaara et al., 2003), and hunting pressure is low (Bodmer \& Pezo, 2001).

Here, we show how the giant otter population has recovered in the Yavarí and Yavarí-Mirín and suggest that this is a direct result of the almost complete cessation of hunting after the Department of Agriculture of Peru (INRENA) banned the commercial hunting of wildlife in 1973 in combination with strict control of trade in skins by CITES. We use population models to predict how giant otter populations on the Yavarí and Yavarí-Mirín may increase further and at what levels they may stabilize.

\section{Study area}

The Yavarí-Mirín River (Fig. 2) is one of the principal tributaries of the Yavarí River, a major white-water tributary of the Amazon that forms the border between Peru and Brazil. The high water season on the Yavarí starts in January and persists until June. However, the YavaríMirín is strongly influenced by local rainfall, and because there is no distinctive rainy and dry season in this part of the Amazon, the Yavarí-Mirín can rise and fall at any point during the year. The visibility of otters in riverside habitats is therefore similar throughout the year on this river. 


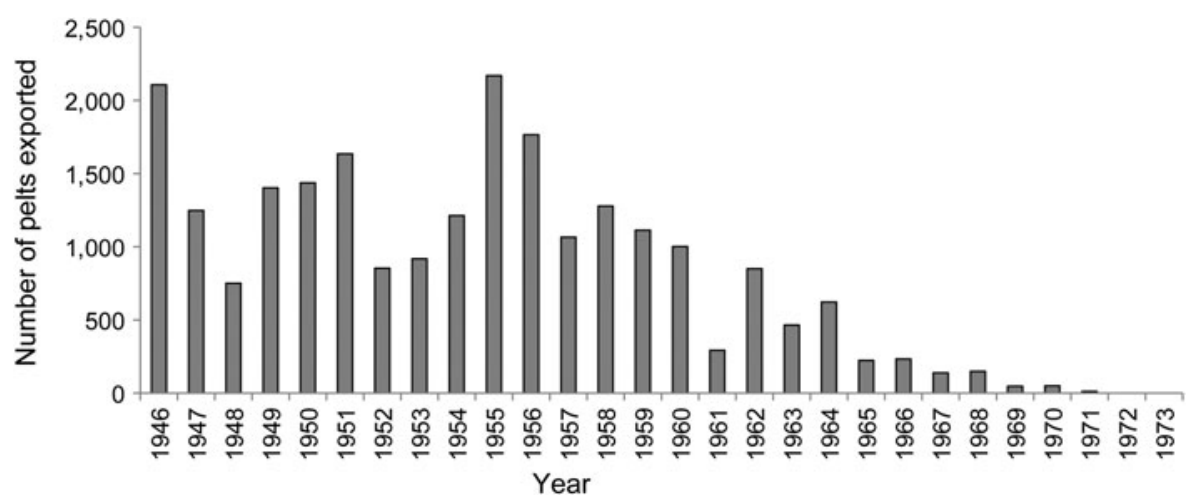

FIG. 1 The number of skins of giant otter Pteronura brasiliensis exported from the Peruvian Amazon during 1946-1973 (adapted from Pacheco, 1983).

\section{Methods}

We conducted 2-month censuses on the middle section of the Yavarí-Mirín River and near the mouth of the YavaríMirín on the Yavarí River in Loreto, Peru, during 19922004 at intervals of 4 years. Censuses in 1992-1993 and 1996-1997 were conducted by R. Bodmer (unpubl. data), and censuses in 2001 were conducted by Isola \& Benavides (2001). We conducted $537.7 \mathrm{~km}$ of censuses in November 2003 and March-April 2004. All researchers in all censuses were trained in giant otter censuses to the same degree and used experienced field guides. Following as closely as possible the recommendations of Van Damme \& Wallace (2005) we used sample counts to compare relative abundance

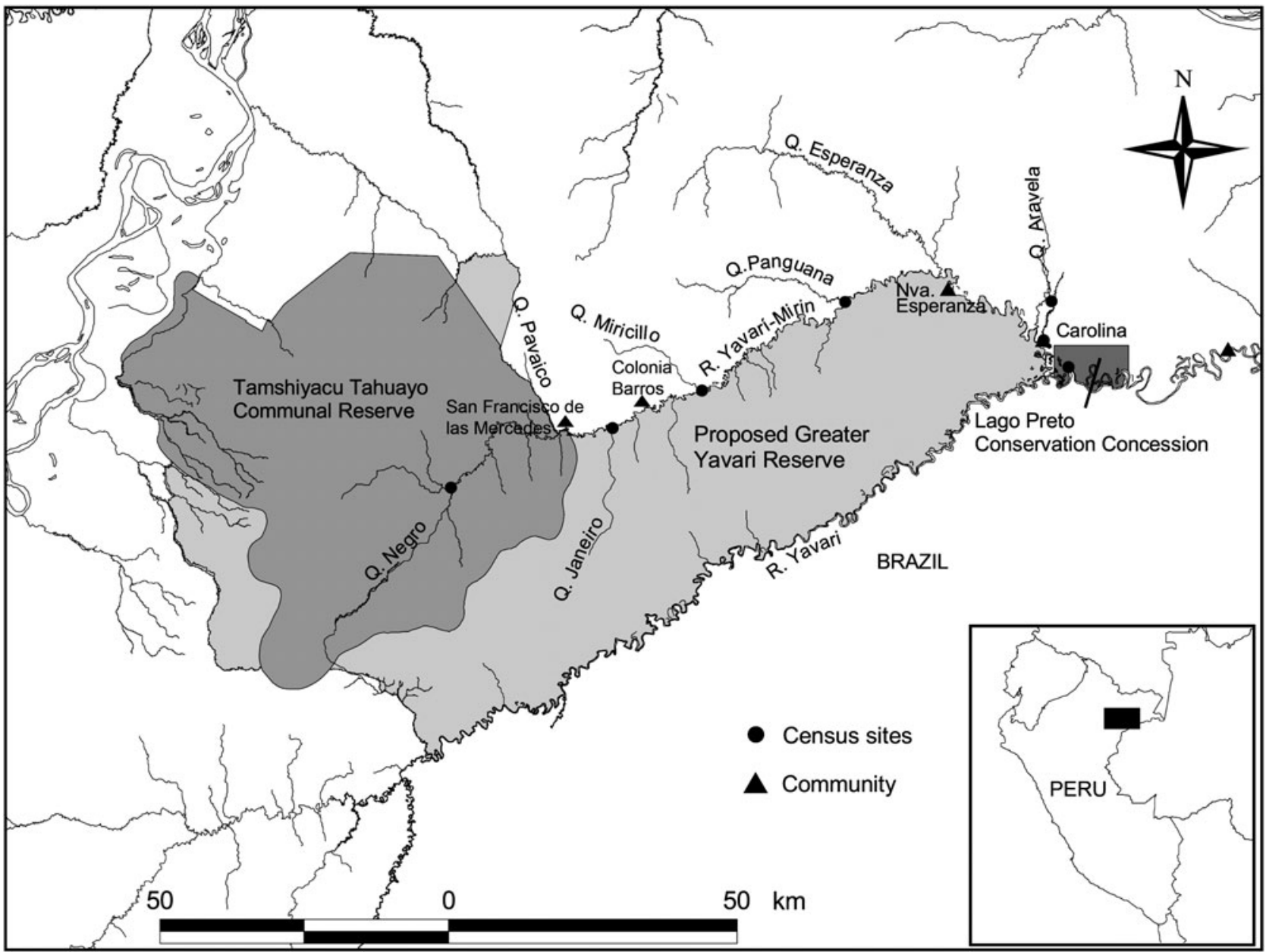

Fig. 2 The study area and census localities for the 2003 and 2004 surveys on the Yavarí and Yavarí-Mirín Rivers. The rectangle on the inset indicates the location of the main figure in Peru. 
between censuses, rather than absolute counts that would have required identification of all individuals in the study area and considerably more time (Groenendijk et al., 2005). Censuses were conducted by paddling downstream by boat, scanning with binoculars and listening for otter calls. We recorded group sizes and locations using a global positioning system, which we also used to calculate the length of each transect. Double counting was avoided by maintaining a constant boat speed and where possible by identifying individual otters by their unique throat markings.

Population change was calculated using $\mathrm{dN} / \mathrm{dt}=r N$, where $N=$ number of individuals in the population and $r=$ intrinsic rate of natural increase. The growth curve for the population was obtained using maximum growth rate, $\operatorname{Max}(\mathrm{dN} / \mathrm{dt}) / K$, where $K=$ the carrying capacity of the ecosystem and Max $(\mathrm{dN} / \mathrm{dt})=$ the point of inflexion of the maximum growth rate.

We determined the influence of humans on giant otters by informal interviews with hunters and fishermen on the Yavarí-Mirín and Yavarí. Interviewees in the villages of Carolina (four fishermen from the total of 21 inhabitants and a police post) and San Francisco de las Mercedes (four fishermen from the total of 14 inhabitants) were asked (in November 2003 and March 2004 respectively) if they hunted or had ever hunted giant otters and how they used the species.

\section{Results}

Between 1993 and 2004 the population of giant otters in the study area increased (Fig. 3). During the first census in 1992-1993 no giant otters were located. Four years later two individuals were observed in the region of an abandoned community, Colonia Barros. This was the first sighting of the species on the Yavarí-Mirín since the ban in trade. Isola \& Benavides (2001) recorded 19 individuals in their census

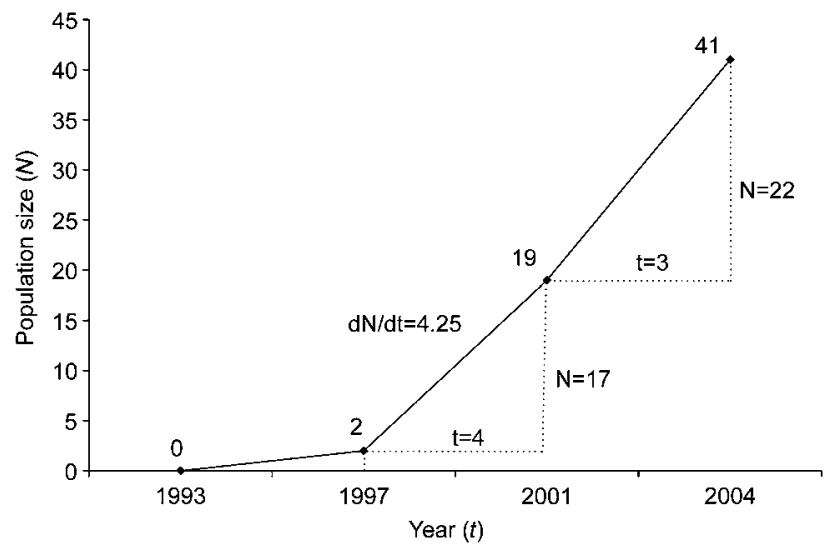

FIG. 3 Population growth curve for giant otters on the Yavarí and Yavarí-Mirín Rivers (Fig. 2), showing the increase in numbers of individuals observed and the growth rate $(\mathrm{dN} / \mathrm{dt})$ between census years. in 2001, and during our 2003-2004 censuses we observed 41 individuals. As the population of otters increased the growth rate increased and the intrinsic rate of natural increase $(r)$ declined, as expected with density-dependent population growth (Fig. 4).

A density-dependent population reaches carrying capacity $(K)$ when $r$ is 0 . Projecting the rate of natural increase to zero gives an estimated $K$ of 142 giant otters (Fig. 5a). When the growth rate $(\mathrm{dN} / \mathrm{dt})$ curve for population size is extrapolated, we can measure the maximum growth rate (Max dN/dt) at the point of inflexion when the population size is $0.5 \mathrm{~K}(71)$, i.e. 8.45 giant otters per year (Fig. $5 \mathrm{~b}$ ). Using the projected growth rate for the population we estimate that $K$ will be reached 20 years from the date of the last census, i.e. in 2023 .

Generally, the interviews suggested that, apart from a few isolated cases, giant otters are rarely hunted because markets and uses for the species are limited, and other animals are easier to find and hunt. Of eight interviewees four mentioned the use of giant otter parts as ornaments. Two interviewees stated that they do not hunt giant otter because there is no economic reason for doing so, and they save their gun cartridges for animals they can sell. One interviewee mentioned that he once sold a skin he had in his house as an ornament to a passing trader. One interviewee mentioned that giant otters make good pets, and one said that the meat of giant otters was good bait for
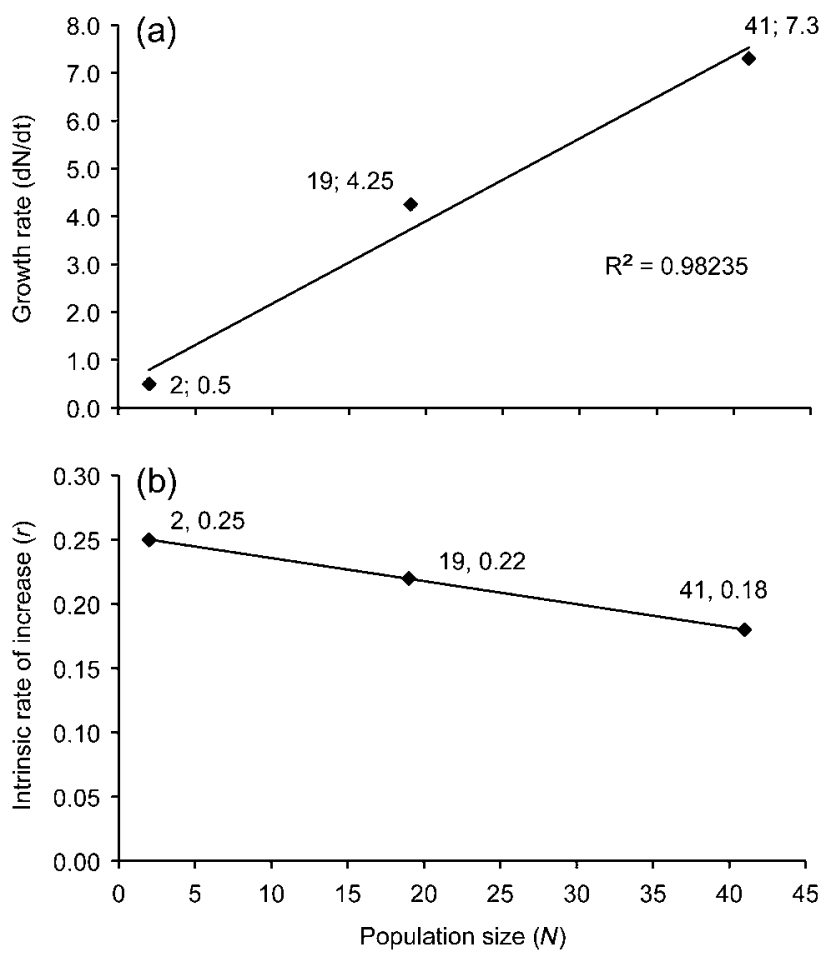

FIG. 4 (a) The growth rate $(\mathrm{dN} / \mathrm{dt})$ and (b) the intrinsic rate of increase $(r)$ of the giant otter population on the Yavari and Yavarí-Mirín Rivers (Fig. 2) at the population sizes recorded in each of the four censuses. 

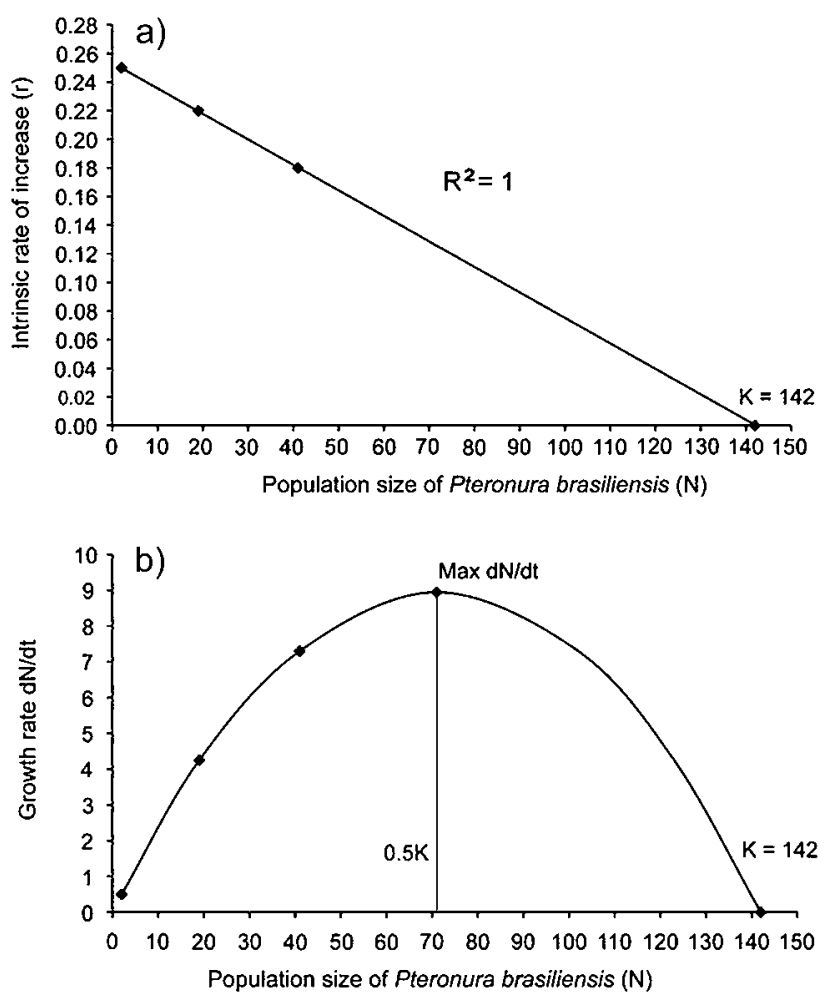

FIG. 5 (a) The projected intrinsic rate of increase $(r)$ for increasing populations of giant otters; $r$ falls to 0 when the population size is 142 , which is therefore the carrying capacity $(K)$. (b) The projected growth rate $(\mathrm{dN} / \mathrm{dt})$ of the giant otter population, showing the maximum growth rate $(8.45)$ at $0.5 \mathrm{~K}$.

capturing yellow-footed tortoise Geochelone denticulata. One young hunter said that he once shot a giant otter because he had never seen one before.

\section{Discussion}

CITES is perhaps the best known international conservation treaty. It was set up to regulate the trade in threatened species and generally prohibits international commercial trade in seriously threatened species (Wells \& Barzdo, 1991). It is now generally acknowledged that for most species habitat loss is a much more significant threat than the international trade in wildlife (Hutton \& Dickson, 2000), and CITES recognizes that wildlife conservation cannot be divorced from wider issues of land use, development and social justice (Hutton \& Dickson, 2000). Clear examples in which CITES has been the key force in saving threatened species are uncommon but a few case studies (Hutton \& Dickson, 2000) show that some species have recovered after inclusion in the CITES treaty (e.g. Nile crocodile Crocodylus niloticus and African elephant Loxodonta africana, Sharp, 1997; citron-crested cockatoo Cacatua sulphurea citrinocristata, Cahill et al., 2006). Several marine mammals may also have benefited from CITES controls (Wells \& Barzdo, 1991).
Overhunting of giant otters and other species between the 1950 s and the 1970s was of concern to the Peruvian authorities and, in 1973, the Peruvian Ministry of Agriculture promulgated a law that prohibited the professional hunting of wildlife in the Peruvian Amazon (Ponce del Prado, 1973). The giant otter was included in Appendix I of CITES in 1973 and, in 1975, international trade restrictions on giant otter skins came into force. The economic benefit of trade in giant otter skins therefore fell. However, overhunting had already led to a reduction in the export of skins because of the extermination of the species in many areas. Regulations prohibiting further trade and loss of the economic benefits of professional hunting acted on an industry that had already almost ended and allowed the recovery of giant otter populations. Although it is possible that the ban by the Peruvian authorities could have reduced hunting pressure on giant otters, it is not clear that the Peruvian authorities could have enforced the ban if international markets for giant otter skins had still existed. Because giant otters were not used within Peru their value was dependent on international trade and, because Peru has long international borders with several countries within the giant otter's range, export of illegally hunted skins would have been relatively easy. The CITES restrictions, however, effectively closed the international markets in North America and Europe and made the hunting of giant otters uneconomical.

The population of the giant otter on the Yavarí-Mirín and Yavarí Rivers underwent a rapid increase after 1992. It appears that the population had reached such low levels that the rate of increase was initially very slow, even though otters can breed from 3 years old and have up to four young per litter annually. But by the late 1990s the population had increased such that the rate of population growth increased. A similar increase may have begun in the Pacaya-Samiria National Reserve in Peru, where Schenck (1999) did not locate any giant otters in 1995 but Isola (2000) recorded a pair of giant otters during a 3-month census in 2000 . The growth of the population in this Park appears to be at an earlier stage than that on the Yavarí-Mirín and Yavarí. Perhaps populations reached even lower levels in this area because of its proximity to the city of Iquitos. Slowly increasing populations have also been recorded in other South American countries (Carter \& Rosas, 1997; Schenck, 1999; Groenendijk et al., 2001).

Populations subjected to high hunting pressure can be reduced to low densities for many years, and the recovery of populations from such low densities to the carrying capacity is slow (Caughley \& Sinclair, 1994). On the YavaríMirín and Yavarí our projections indicate that giant otter populations will reach carrying capacity in c. 2023, 50 years after CITES imposed the ban on the trade in skins. Population growth will slow as intraspecific competition increases, with suitable home ranges becoming occupied. 
However, the recovering giant otter population in the Yavarí-Mirín is likely to act as a source area for the surrounding region, including the Tamshiyacu-Tahuayo Communal Reserve.

The hunting of giant otters on the Yavarí-Mirín and Yavarí has been halted. Some giant otters may occasionally be captured as pets or shot but this is unlikely greatly to affect the otter population. The use of giant otter meat as bait for capturing tortoises may also occur but interviewees said that more common and easily hunted animals, such as caiman Caiman crocodilus, are used more commonly for bait. Forestry concessions were established along the north bank of the Yavarí-Mirín and Yavarí in 2003-2004 but the logging in these concessions is selective and is likely to have limited long-term impact on the area. However, logging activity is concentrated around rivers and streams, which are use to transport timber from the forest. Disturbance may affect the breeding success of giant otters, and loggers who hunt for subsistence may not share the selective hunting practices of residents.

As the giant otter population on the Yavarí-Mirín and Yavarí Rivers grows other conservation issues are likely to become important. Fish are the principal diet of the giant otter, and communities on the Yavarí and Yavarí-Mirín also depend largely on fish. Commercial fishermen from Brazil, Peru and Colombia also frequently use lakes on the Yavarí. Fishermen often consider the giant otter a competitor for fish. If larger otter populations lead to conflict between otters and local people or commercial fishermen, more otters may be hunted. In addition, giant otters are susceptible to parvovirus transmitted by domestic dogs (Schenck, 1999). Dogs were present in all communities visited on the Yavarí-Mirín and Yavarí. While there are no data on the prevalence of this or other diseases or on the likelihood of contact or transmission between dogs and giant otters, an epidemic of this or another disease is a possibility. These additional issues will become the focus of giant otter conservation in the Peruvian Amazon but it is the success of CITES in closing the market for otter skins that, in the absence of adequate controls to prevent illegal hunting and trade within Peru, ended the widespread commercial hunting of this species. This has enabled this species to persist in this area and for the population to recover.

\section{Acknowledgements}

We thank the Durrell Institute of Conservation and Ecology and Wildlife Conservation Society (Peru) who provided support in the field, Sandra Isola for her census work, also our field assistants, particularly Jorge Pacaya, Edwin Pinedo and Oliver Rodríguez, and Mark Bowler, Miguel Antunez and Pedro Perez for comments on drafts and for help with the figures.

\section{References}

Bodmer, R.E. \& Pezo, E. (2001) Rural development and sustainable wildlife use in Peru. Conservation Biology, 15, 1163-1170.

Bodmer, R.E. \& Puertas, P. (2003) A brief history of the Yavari Valley. In Peru: Yavari. Rapid Biological Inventories Report 11 (eds N. Pitman, C. Vriesendorp \& D. Moskovits), pp. 172-176. The Field Museum, Chicago, USA.

Cahill, A., Walker, J. \& Marsden, S. (2006) Recovery within a population of the Critically Endangered citron-crested cockatoo Cacatua sulphurea citrinocristata in Indonesia after 10 years of international trade control. Oryx, 40, 161-167.

Carter, S.K. \& Rosas, F.C.W. (1997) Biology and conservation of the giant otter Pteronura brasiliensis. Mammal Review, 27, $1-26$.

Caughley, G. \& Sinclair, A.R.E. (1994) Wildlife Ecology and Management. Blackwell Science, Oxford, UK.

Duplaix, N., Waldemarin, H.F., Groenedijk, J., Munis, M., Valesco, M. \& Botello, J.C. (2008) Pteronura brasiliensis. In IUCN Red List of Threatened Species v. 2009.1. Http://www.iucnredlist.org [accessed 12 September 2009].

Eisenberg, J. (1989) Mammals of the Neotropics. The Northern Neotropics. Volume 1. The University of Chicago Press, Chicago, USA.

Groenendij, J., Hajek, F., Schenck, C. \& Staib, E. (2001) Monitoreo del Lobo de Río (Pteronura brasiliensis) en la Reserva de Biosfera del Manu: metodologías y resultados. In El Manú y otras experiences de investigación y manejo de bosques tropicales, Symposium Internacional. Puerto Maldonado, Peru. 4-7 June 2001 (ed. L.O. Rodríguez), pp. 150-153. Proyecto Pro Manu, Lima, Peru.

Groenendijk, J., Hajek, F., Duplaix, N., Reuther, C., Van Damme, P., Schenck, C. et al. (2005) Surveying and monitoring distribution and population trends of the giant otter (Pteronura brasiliensis). Habitat, 16, 1-53.

Hutton, J.M. \& Dickson, B. (2000) Endangered Species, Threatened Convention. The Past, Present and Future of CITES. Earthscan, London, UK.

Isola, S. (2000) Determinación de la distribución y abundancia de lobo de río (Pteronura brasiliensis) en la Reserva Nacional Pacaya Samiria. BSc thesis, Universidad Nacional Agraria La Molina, Lima, Peru.

Isola, S \& Benavides, J. (2001) El Lobo de río: Una especie bandera para la reserva comunal Tamshiyacu Tahuayo. Unpublished Report. Universidad Nacional Agraria La Molina, Lima, Peru.

Pacheco, T. (1983) Efectos positivos y negativos de la veda de caza de 1973 en la amazonia peruana. Universidad Nacional Agraria La Molina, Programa Académico de Graduados, Lima, Peru.

Ponce Del Prado, C.F. (1973) Informe Nacional sobre Fauna del Peru. Simposio Internacional de Fauna Silvestre y Pesca Fluvial y Lacustre Amazónica. IBDF, Manaus, Brazil.

Salovatia, K., Bodmer, R.E., Recharte, M. \& Reyes, C. (2003) Diversity and abundance of mammals. In Peru: Yavari. Rapid Biological Inventories Report 11 (eds N. Pitman, C. Vriesendorp \& D. Moskovits), pp. 156-164. The Field Museum, Chicago, USA.

SCHENCK, C. (1999) Lobo de río Pteronura brasiliensis, presencia, uso del hábitat y protección en el Peru. Agencia de Cooperación Técnica Alemana (GTZ) and Instituto Nacional de Áreas Naturales Protegidas, Lima, Peru.

SHARP, R. (1997) The African elephant: conservation and CITES. Oryx, 31, 111-119.

Smith, N. (1981) Caimans, capybaras, otters, manatees, and man in Amazonia. Biological Conservation, 19, 177-187. 
Utreras, V. \& Jorgenson, J. (2003) Aspectos de la cacería y la distribución actual e histórica de la nutria gigante (Pteronura brasiliensis) en la Amazonía Ecuatoriana. En Manejo de Fauna Silvestre en Amazonía y Latinoamérica. Selección de trabajos $\mathrm{V}$ Congreso Internacional, Colombia.

Van Damme, P. \& Wallace, R. (2005) Considerations on measuring giant otter (Pteronura brasiliensis) relative abundance for conservation planning. Revista Boliviana de Ecología y Conservación Ambiental, 17, 65-76.

Wells, S.M. \& BARzDo, J.G. (1991) International trade in marine species: is CITES a useful control mechanism? Coastal Management, 19, 135-154.

\section{Biographical sketches}

Maribel Recharte Uscamaita has worked for the Wildlife Conservation Society in Peru since 2006 on the ecology of Amazonian mammals, sustainability of hunting in the Peruvian Amazon and community-based conservation, and she continues to work on giant otters. Richard Bodmer has worked on ungulates and sustainable resource use since 1986. His current research focuses on the biology, conservation and sustainable use of Amazonian wildlife, the diversity of tropical mammals, the ecology of Amazonian mammals, sustainable hunting in the tropics and community-based conservation. 